\title{
Review:
}

\section{Now Playing at Canterbury}

\section{Peter Dufour}

Katherine Anne Porter, in the preface to her Collected Stories, wrote that the English language has four terms to cover the wide range of dramatic fiction: short stories, long stories, short novels, and novels. On the surface of things, that seems to cover just about everything. Unfortunately, there is no single, convenient term to describe Vance Bourjaily's Now Playing at Canterbury. It's not quite a novel, although there is a nicely developed narrative thread binding its various sections together; it's not quite an anthology of short and long stories, although it includes a number of them, some of them already published in some form or other in places as disparate as Esquire, North American Review, Boy's Life, and 
Dude. Of course, the book!s title should remind us of its antecedent and its form -- that is, a fairly random selection of people gathered together begin to tell each other stories.

But this time, instead of going on a religious pilgrimage, the people have gathered in the American Midwest of the early 1970s to put on an opera concerning a construction crew in the Deep South of the late 1940s. And, like their holier counterparts, the people gathered at State University in State City -- modeled on Iowa City, Iowa -- tell stories which range from autobiographical snippets to animal stories. But on whatever level (if such a level exists at all) Now Playing at Canterbury pretends to the lofty heights of its predecessor, it fails: it has neither the inspired cosmology of Chaucer nor the ability to call itself a human comedy. But such quibbling need not hinder our appreciation of Bourjaily's accomplishment. While the book is certainly not the finest work of fiction to appear in the last few years, it takes its place easily, albeit oddly, among the ranks of the very good.

Oddly: that's the important word here. Comparing this book to other recent and celebrated fictions is nearly impossible. Canterbury has 
IOWA JOURNAL OF LITERARY STUDIES - 21

neither the power, audacity, nor authority of Pynchon's Gravity's Rainbow nor Gaddis's JR. But neither has it any of the calculatedly interminable banality of Heller's Something Happened. In fact, it defies comparison of this sort. The closest thing to it in form might be John Gardner's October Light with its interpolated pulp novel, but even this is misleading. Bourjaily's book goes further, takes more chances, and is considerably more spastic. It works altogether differently: its effect is subtle and cumulative, often difficult and frequently frustrating. It forces the reader to particioate, to grasp at the fine points of character and plot development, to perceive the correspondence between the real-life actualities of the assembled cast and crew and the stories they tell to each other. As the omniscient narrator puts it at the book's outset, there are "many voices to hear and some to heed," but the voices themselves are often suspect. As the opera's librettist, Rigby "Snazzer" Short, answers when asked what happens "'when a group of people's brought together by chance for a while"": "They Tell lies.. ." And lie they do. Oscar Wilde can rest easily for a while: the art of lying has scaled new heights in State City. 
Everything in the book is centered around the opera $\$ 4000$ which involves a lengthy poker game and a contested pot. The ploc is ackittedly "too melodramatic; but isn't opera always melodramatic?" Evolving from the musical and technical aspects and problems of the opera's production is a larger depiction of the Midwestern ambience in a university town. But this thread which ties the whole book together is hardly spare or skeletal. While the major characters in the story rehearse their parts or tell their stories, the sheriff's department somewhat ineptly investigates the theft of some nearly worthless religious paintings from the art museum and decides to make a token drug bust which nets no dope but rather an impressive collection of worthless religious paintings. Bourjaily also furnishes us with a number of episodes exploring the institution of marriage in the modern day as well as the vagaries of sexual liberation and constriction. This, then, is what we have in the way of a center. But the various stories, the lies as it were, are the real meat of the book. They are of primary interest largely because they furnish us with the material necessary to judge the participants. 
Just as one might well expect, however, the degree of success of the various stories is not always equivalent. Instead, the quality of the stories ranges from the lame to the sublime, with most of the tales falling toward the latter end of the spectrum. Bourjaily reportedly spent twelve years working on this book, and during that time it seems that he decided to experiment with form. One story, that of the orchestra conductor, Sato Murasaki, is told completely by means of comic strip balloons. Unfortunately, the form does little in the way of furthering the impact of the story even though the story does compel some interest. Another segment, the one spoken by Davey Riding, tenor, is told in heroic couplets. While I admired Bourjaily's resourcefulness and daring in this respect, my reaction was close to nausea: the story is basically uninteresting and the singsong rhetoric is cloying. But the most naive story of the bunch, a rehashing of the fable of the tortoise -- this time on rollerskates -- and the hare, is also one of the most telling. It is told by the simplest member of the cast, soprano Sidney Bennet (née Cindy Benesch), and by means of its amoral message the reader is able to see just what it is 
about this insipid nymphet tease that makes her almost totally reprehensible both off and on the stage.

When Bourjaily gets cracking, by God, the results are marvelous. From an academic standpoint, the most interesting tale is a recurring dream suffered by Snazzer Short in which F. Scott Fitzgerald incarnate appears at a meeting of Short's graduate seminar on Fitzgerald. Making matters worse, he appears on the day the class is considering Fitzgerald's least accomplishment, Flappers and Philosophers. It is the same day that one of the more outspoken graduate students sees fit to speak out in favor of "The offshore Pirate" to the extent of almost denying the accomplishments of "Bernice Bobs Her Hair" and other more worthy stories. Short is, of course, quite uncomfortable in this strange situation, which is made even worse by Fitzgerald's bemused reaction to the brouhaha surrounding his posthumous reputation. Finally feeling his detached reason give way to his raving temper, Short screams, "'How can you people be in graduate school and not have learned to read yet? Well? Do you think I'm asking rhetorically? I want answers, I may even want nine answers in writing. 
Well?'" As Short's decorum and pride vanish, he glimpses Fitzgerald leaving the classroom with the worst student, a vapid sorority girl. While such a conclusion is perfectly logical with respect to Fitzgerald's own tastes, it is a terrible blow to the disenchanted, dishevelled short.

There is also an excellent adventure of roadracing in the mountains of Mexico told by Dr. Johnny Ten Mason, M.D. It is, in fact, a classic of the genre. And, like most of the very good stories in this book, it stands by itself apart from the whole book as an example of what fiction's first requirement should be: to entertain The story is completely realized, and it holds our attention so well that one thinks only much later about its perhaps being just another tall tale, just another lie. An automobile also figures prominently in the story told by Australian-born, pompous Hughmore Skeats. Skeats, who is constantly given to an affected, British Empire rhetoric (for instance, "Absobloodyfuckinglutely"), tells the tale of his drunken discharge from the U.S. Anmy at the end of World War II. Only in this reminiscence of his youth can one see the human and humorous side of this baritone jackass.

Some of the stories are interrelated, and two 
of these are wincingly discomfiting in their detail. Both deal with castration -- one with regard to the removal and gastronomical preparation of beef testicles, the other with regard to the attempt to make Marcel St. Edouard, the major tenor in the opera, into a castrato during his youth. Marcel's story concerns a monomaniacal stepfather determined to resurrect the grand music written for castrati in centuries past, a nearly idiot mother blind to the threat her husband's monomania poses to prepubescent Marcel's incipient manhood, and Marcel and his clarinet.

While the situation of this story is interesting enough, one has to stand back and marvel at another of Bourjaily's great attributes: the impression he gives of knowing a little or a lot about almost anything -- from music, art, and literature to automotive and mammalian anatomy. Perhaps one might tender the criticism that the book is more than slightly studied in tone. It is. But that's not necessarily a hindrance or a defect. One must keep in mind that this is neither allegory nor sociology. Instead, it is a collection of generally well-informed and well-educated voices. There is no Big Statement being made here. There are, however, a number of little statements being made about how 
people -- particularized individuals who may or may not share any characteristics with us as individuals -- live their various lives and react to their own situations, adverse or otherwise.

In my own mind, there are two stories which tower over the others in terms of entertainment, suspense, drama, and -- often in a somewhat perverse sense -- humor. The first concerns a pack of maneating housecats, led by a cream-colored thirtypound monster, which finds its inevitable demise in the paws and teeth of a wild pack of marauding dogs, led by a sagging-bellied beagle bitch. Iooking now at my description of the situation of this story, I have to chuckle at what should be an obvious absurdity. Take my word for it, however: you may never again seek out that soothing purr or do anything to offend that little tabby.

Even better is a recollection of the Vietnam War protests of the late sixties and early seventies. It is a long, amazingly balanced segment highlighted by "Crazy Betty, the rat flogger." Against the background of the peaceful protest movement turning quickly into a violent ramage, the story of Betty's inability to experience conventional sex, her marriage to an ineffectual West Coast drug dealer, her two rapes, and two 
28 - IOWA JOURNAL OF LITERARY STUDIES

rats named Lyndon and Tricky-Dicky turns out to be one of the most complete and sensitive portraits of campus protest and violence during that period, as well as the best single story in the book. Through it we can see the scrubbed-face idealism of the sixties sour into the rage and divisiveness of the seventies. As a political statement it says very little, but as a fictional re-creation of the events and moods of the period it is superb. Thankfully, it is nearly devoid of the ideological doctrines being tossed about during "America!s cold Civil War." That is not to say, however, that it lacks commitment. Bourjaily makes us sympathize with the student "heterogeny of flakes" in the "War of the Ice Men Against the Snow Flakes." But the narrative, like history, has no happy ending. In fact, our heroes lose nearly everything, and Betty loses all. Not all the action takes place in the stories and reminiscences, however. One of the best sequences in the book concerns an orgy in the Wisconsin woods attended by Dr. Johnny Ten Mason and his newfound lover, alto Beth Paulus. If I read this section correctly, then Bourjaily is most certainly and incisively satirizing all the updikean sex-in-surburbia crapola that has permeated American fiction since the late 1950s. It must be 
satire: how else would one account for this bloodless, mechanical description of three-way sex involving a rich University benefactor Hervey Gandenberg (who made his fortune "on the three B's: bellies, beans, and beets"), on the bottom, a famous soprano, Janet Margesson, sandwiched in the middle, and Johnny Ten making the rear entry from the top:

Lubricant lacking but perhaps unnecessary. Ee hoists a leg over, adjusts position, and penetrates cquickly. There is some resistance in the lower part of the passage, a request ("Easy, darling"), in reply to which he inflicts a thrust both deft and uncompromising. ("Oooch.") And what he feels, after an imoulse of triumph, is Hervey Gandenberg, on the other side of the rectovaginal septum. Over on his side of the wall Gandenberg, for Christ's sake, is getting a massage; quickly, before the idea nauseates him, Johnny calls up an anatomical cross section of what's between them: There's Gandenberg, vaginal mucosis, muscle, fibrous tissue, membrane in the middle, fibrous tissue, muscle, rectal mucosis. Jesus, what's the membrane called? All he can bring to mind is the voice of a lecturer comparing it to Saran Wrap. Thrusts, trying to concentrate on what Margesson's sensation will be. Not high sensitivity, just pressure. Suddenly begins to laugh at himself, internally, pressurizing her Saran Irap; what the hell kind of gratification; Hervey's? Something in the mind? 
In fact, all the sex in this sequence lacks any sort of erotic sensation. It concludes with a Mansonesque climax in which Beth is nearly, quite literally, fed to the dogs.

In a book so replete with stories, there is great irony in what Johnny Ten has to tell the rest of the cast back in State City about the goings-on in the woods. After taking Gandenberg's station wagon and speeding back to rehearsal, Johnny wearily tells Snazzer, making no excuses, "'there isn't any story. . ."

The ending of the book is perhaps a bit melodramatic. But the more I think about it, the less I'm convinced that it's a fault. Any work of fiction is, out of narrative as well as historical necessity, going to belie some sort of topical bias or concern. The ending of Canterbury concludes the story of Vietnam war protest with a vengeance. Given the time, 1972, and the failure of the domestic protest movement, the last story in the book quite logically and legitimately brings the reader into the last battles of the war -- this time in Hanoi. The conclusion is a bit extreme, but it is told, not with bitterness, but with indecision -should one doubt the efficacy of one's efforts to effect some sort of change in a democratic society, 
or should one learn to accept the reality of continuing defeats? If there is a single theme binding the many parts of this book, then it is this kind of defeat; for no one is truly victorious on stage or in the real world. It is the lesson which dominates the life and career of Billy Hoffman, the director, who, more than any other character, provides a focus for the book. It is this strange ending, I think, which prompted Peter S. Prescott of Newsweek to say, in his review of Canterbury, that Bourjaily "gives us America at the same remove from reality that television gives it to us." of course, Prescott is right in this respect, but it's my inpression that he fundamentally misunderstands both the nature of the idealistic commitment of the early seventies and the book itself. The book does, of course, represent some sort of "remove from reality" the same way that any work of literature represents some sort of detachment, as well as an inability to make its audience "really" participate in the fiction. That is Prescott asking for -- a piece of snot-begrimed realism so convincing in its massing of details and situations that it would no longer resemble this book which only tenuously rests on the edge of realism? 
If Prescott's criticism (I use that word broadly when speaking of Newsweek reviews) tells us anything, then it is more about the condition of popular, newsmagazine criticism than it is about the book. Seen as a whole, Prescott's review is snivelling, snide, and destructive -- more so to Prescott's own credibility than to Bourjaily's ability to write fiction. It includes such gems as "It's a big book, all right . . but as a novel it's a mess -- pretentious, shallow, complacent and mannered often to the point of self-indulgence." One might just as well apply this comment to any number of books ranging from Tristram Shandy and Moby-Dick to The Valley of the Dolls. In effect, the statement is meaningless, for Prescott only glosses over what he considers the defects, at times coming perilously close to misrepresentation. He is unwilling, it seems, to accept any sort of departure from the conventional patterms and forms of modern American fiction. Do we really need this? But such pop-crit works both ways. Tebster Schott in The New York Times Book Review comes to Bourjaily's defense, but his raves are almost as insipid as Prescott's ranting. Canterbury is, he writes, "of its time, as John Dos Passos's U.S.A. was, as William Gaddis's JR is. It's a gigantic 
human envelope holding sections of our immediate, beautiful and brutal world." I tend to chuckle at overkill, but my sensibility is wrenched by these comparisons. The resemblances are so strained or superficial that they seem to me to have very little in common indeed. Bourjaily's book hardly has some grandiose sense of The Norld. It is specifically located in time and place, and its characters are not at all representative of Everypersons. Besides that, what in the hell is a "gigantic human envelope"?

Now, as if this weren't enough, Schott takes great pain to refer to Iowa City -- Bourjaily's teaching residence as well as the real-life counterpart of State City -- as "Montmartre of the Midwest." Wha? A slight exaggeration, I might say, unless one also sees Iowa City's lovely Clinton Street Mall -- a row of mobile homes perched in the middle of a downtown street filled with businesses displaced by the eternal ravages of urban renewal -- as the serene equivalent of the Champs Elysees. I'm certain that schott is referring to Iowa City's artistic community, what with the celebrated Writers' Workshop and all, but such comments as these are hardly necessary in a review for a prestigious publication: they amount, 
quite simply, to gushing drek.

As long as I've gone this far, I might as well mention a fine example of one of those animals usually referred to as a "generally favorable" review although we all know that the critic's remarks amount to no more than an inadequate ambivalence. Geoffrey Wolff, reviewing Canterbury in New Times (that journalistic mishmash of Now Generation sentiment and sentimentality), doesn't seem to know on which side of the fence to stand, but he keeps on talking anyway. Some of his perceptions of the books are, I admit, precise and insightful, but one comes away from the piece unable to discern how rolff really feels about the book. Along the way we learn that Bourjaily erred in his description of a Porsche engine, but I wonder if such picayune matters are better left unsaid when the reviewer has only about a thousand words to speak his piece in. As along as we're talking about inessentials, though, I'd like to take a look at Wolff's comment that "Bourjaily is at pains to remind readers that he himself wrote the libretto for an opera of the same name (i.e., $\$ 4000)$ performed at Iowa State University. . ." Now, my copy of the book distinctly places that performance at the University of Iowa, and, while 
I am not offended in the least by rolff's less than egregious mistake, there are some wags who hold that confusing the University of Iowa with Iowa State University is like confusing the Bolshoi Ballet with a herd of splayfooted cattle.

Perhaps the fault lies not with the reviewers, but rather with the publication strictures under which they must write -- length, stylistic inelegance, etc. In the nineteenth-century, at least, a book review was much more than it is now. It was a forum for artistic and literary debate as well as a sounding board for aesthetic bias and bigotry. If Poe were not remembered for his poetry and fiction, then we would still probably read him for his articulate reviews. But today the review is a bloodless, sterile thing, encased in a New York office building. It rarely provokes any sort of thought more than a subliminal urge to buy a book or spit on it. Such is our great loss and such is my bellyache.

But I digress; Bourjaily's book is the important thing here. And I reiterate that Now Playing at Canterbury is an important book, though not quite the "bona fide American masterpiece" its dust cover calls it. While our native folk traditions may be dead, the story form definitely 
lives in our literature. Bourjaily has creditably demonstrated its vitality and intensity; the power of entertainment for the sake of entertainment can still move us. This is how Bourjaily sums it up, and I can't think of any words to say it better: "There's a story you could tell to pass the time as the lovely, polluted California seascape passes. So could we all, every man his own Homer, blind, caught in the endless wonder of the words, of the cries, of the shouts, of the laughter, of the tears of the things of the stories of our lives." 